\title{
Criança-Soldado / Child Soldiers
}

https://doi.org/10.21814/uminho.ed.36.17

\section{Utsa Mukherjee}

Brunel University London, United Kingdom 



\section{Crianças-Soldado}

O termo criança-soldado é notoriamente difícil de definir, uma vez que as noções de infância e de soldado são processos sociais contingentes que assumem um conjunto de significados diferentes ao longo do tempo e do espaço. O Simpósio da Cidade do Cabo, em 1997, e os seus sucessores, os designados Princípios de Paris de 2007 e os Princípios de Vancouver de 2017, têm uma visão ampla da criança-soldado como qualquer pessoa com menos de 18 anos que está envolvida com um grupo armado em qualquer função - inclusive como guerrilheiros, espiões, cozinheiros ou recrutados para fins sexuais, entre outros. 0 artigo $38 .^{\circ}$ da Convenção das Nações Unidas sobre os Direitos da Criança (ONU) de 1989 contém um Protocolo Opcional que exige que os Estados signatários garantam que crianças menores de 15 anos não participem em conflitos armados e que os Estados não recrutem menores de 15 anos para as suas forças armadas. Até agora, 168 dos 197 Estados-Membros da ONU ratificaram este protocolo opcional. No entanto, o Secretariado do Enviado do Secretário-Geral da ONU para a Juventude, estima que 300.000 crianças em mais de 20 países - $40 \%$ das quais são meninas - participavam em conflitos armados, em 2015. De acordo com o Child Soldier Wold Index, do Child Soldiers Initiative's, de Roméo Dallaire, desde 2016, existiram crianças envolvidas em conflitos armados em, pelo menos, 18 países de todo o mundo e 46 países que ainda recrutam menores de 18 anos para as suas forças armadas.

As repetidas tentativas internacionais para definir uma criança-soldado manifestadas nos Princípios da Cidade do Cabo, Paris e Vancouver - são sustentadas por suposições contemporâneas sobre a infância, o conflito armado e a relação entre estes dois. Elas trazem para primeiro plano a definição da CDC de criança como alguém que tem 18 anos ou menos um conceito particular de delimitação de idade e curso de vida que não se reflete, do mesmo modo, em todas as formações sociais do mundo. As ideias sobre quem conta enquanto criança, que responsabilidades tem e 0 que marca a sua transição para a vida adulta são socialmente construídas e, portanto, diferentes estruturas foram desenvolvidas pelas sociedades ao longo do tempo e do espaço, para se pensar sobre quem é uma criança num contexto particular. 
Essas questões acrescentam complexidade a um entendimento sociológico das crianças-soldado. Tomemos, por exemplo, o caso de dois meninos de 13 anos ativamente envolvidos em conflitos armados: Andrew Jackson uma criança-soldado durante a Revolução Americana e futuro presidente dos Estados Unidos - e Ishmael Beah - uma criança-soldado convocado para a guerra civil na Serra Leoa e que, mais tarde, se tornou o primeiro Advogado da UNICEF para Crianças Afetadas pela Guerra. Como observou David Rosen (2015), Jackson - como muitas outras crianças-soldado da Guerra Revolucionária Americana e, mais tarde, da Guerra Civil Americana é celebrado como um patriota e um herói nacional pelo envolvimento em conflitos armados, enquanto Beah é visto enquanto vítima de manipulação e abuso de adultos durante um conflito armado. Ainda que ambos tivessem 13 anos quando fizeram parte desses conflitos armados, as suas histórias estão separadas por 213 anos, período durante o qual a compreensão coletiva predominante de quem conta como uma criança e onde devem pertencer em cada sociedade se modificou radicalmente, bem como a nossa compreensão do lugar das crianças em conflitos armados.

O debate sociológico sobre as crianças-soldado levanta um conjunto de questões críticas sobre o modo como podemos diferenciar o que constitui um recrutamento forçado de crianças para conflitos armados e a sua participação voluntária nos mesmos. Desconstruí-las depende muito do contexto social: o modo como se desenham os limites quotidianos da violência numa dada sociedade e a estrutura mais vasta do aparelho de estado, as relações de género, as divisões étnicas e de classe, nas quais as ideias de conflito, noções culturais de infância e quadros prevalentes para a resolução de conflito estão inseridos. Sem ter estas formações de relações sociais em conta, o entendimento das experiências das crianças na Guerra e os seus esforços na reintegração social, serão objetivos difíceis de atingir. Além disso, estes debates contêm questões fundamentais sobre as estruturas que governam as vidas quotidianas das crianças, sobre o modo como imaginamos uma infância ideal - particularmente as assunções sobre a sua inocência inerente -, e as mudanças nas capacidades corporais das crianças. Os corpos das crianças-soldado transformam-se em veículos fundamentais dos conflitos armados, onde se inscrevem, fisicamente, as insígnias do grupo armado, e que são usados como carregadores e espiões, para lá do seu papel como lutadores armados (ver Denov, 2010). Do mesmo modo, a vulnerabilidade e potencial desenvolvimental dos corpos das crianças são invocados em campanhas para a prevenção do recrutamento e uso de crianças em conflitos armados. Enquanto os conflitos armados e a violência continuam a crescer em todo o mundo, a Sociologia da Infância tem um contributo 
importante nos debates públicos sobre crianças-soldado, colocando a atenção nos contextos culturais e estruturas históricas socialmente construídos nos quais se inserem os conflitos em geral e as crianças-soldado, em particular. Estes contributos sociológicos poderão ajudar a construir respostas políticas culturalmente sensíveis para este fenómeno sociolegal.

\section{Child Soldiers}

The term child soldier is notoriously difficult to define because the notion of childhood and that of soldiering are contingent social processes that take on different sets of meanings across time and space. The Cape Town symposium in 1997 and its successors, the so-called Paris Principles of 2007 and Vancouver Principles of 2017, take a wide-ranging view of a child soldier as anyone under the age of 18 who is involved with an armed group in any capacity - including fighters, spies, cooks or those recruited for sexual purposes among others. Article 38 of the United Nations Convention on the Rights of the Child (UNCRC) 1989 contains an optional protocol that requires signatory states to ensure that children under the age of 15 do not take part in hostilities and that states should not recruit under-15s in their armed forces. Till now, 168 out of 197 UN Member States have ratified the optional protocol. Nevertheless, the Office of the UN Secretary-General's Envoy on Youth estimates that 300,000 children in over 20 countries $-40 \%$ of whom are girls - were taking part in armed combat as of 2015. According to The Roméo Dallaire Child Soldiers Initiative's Child Soldier World Index, since 2016 children have been involved in at least 18 armed conflicts around the world with 46 countries still recruiting under-18s in their armed forces.

Repeated international attempts at defining a child soldier - manifest in Cape Town, Paris and Vancouver Principles - are underpinned by contemporary assumptions about childhood, armed conflict and the relation between the two. It foregrounds the UNCRC definition of a child as someone who is 18 years of age or younger - a particular concept of age and life course demarcation that is not reflected in all social formations across the globe. Ideas about who counts as a child, what responsibilities children have, and what marks their transition into adulthood are socially constructed and hence different frameworks have been deployed by societies across time and place to think about who a child is in his/her particular context. These questions add further complexity to a sociological understanding of child soldiers. Take for instance the case of two 13-year-old boys actively 
involved in armed conflicts: Andrew Jackson - a child soldier during the American Revolution and the future president of the USA - and Ishmael Beah - a child soldier drafted into the civil war in Sierra Leone who later became UNICEF's first Advocate for Children Affected by War. As David Rosen (2015) has shown, Jackson - like many other child soldiers from the American Revolutionary war and later the American Civil War - is celebrated as a patriot and a national hero for his involvement in armed conflict whilst Beah is valorised as a victim of adult manipulation and abuse during an armed conflict. Although they were both 13 when they were part of armed conflict, their stories are separated by 213 years during which time our prevalent understanding of who counts as children and of where they should belong in society has radically transformed and so has our understanding of children's place in an armed conflict.

The sociological debate about child soldiers raises a range of critical questions about how to differentiate between forced recruitment of children into armed conflict and their voluntary participation. Indeed, one can call into question whether such demarcations can be made in the first place. Unpacking these issues has much to do with the social context: how limits of everyday violence are drawn in a given society and the wider structures of state apparatus, gender relations, class and ethnic divisions in which ideas of conflict, cultural notions of childhood and prevalent frameworks for conflict resolution are embedded. Without taking these social relational formations into account, understanding children's experience of war and efforts towards their reintegration into the mainstream will be difficult to accomplish. Moreover, encapsulated in these debates are fundamental questions about the structures that govern children's everyday lives, how we imagine an ideal childhood - especially assumptions about inherent innocence -, and children's changing bodily capacities. The bodies of child soldiers become key vehicles for armed conflicts with their bodies often physically inscribed by the insignia of the armed group and used as porters and spies apart from their role as armed fighters (see Denov, 2010). Equally, the vulnerability and developmental potential of children's bodies are invoked in campaigns for the prevention of children's recruitment and use in situations of armed conflict. As armed conflicts and violence continue to rage in different corners of the globe, the sociology of childhood has an important contribution to make in informing public debates about child soldiers by drawing attention to the cultural contexts and historically constituted structures in which conflicts in general and child soldiers in particular are embedded. Such sociological understandings can help shape culturally sensitive policy responses to this socio-legal phenomenon. 


\section{Referências / References}

Denov, M. (2010). Child Soldiers: Sierra Leone's Revolutionary United Front. Cambridge: Cambridge University Press.

Rosen, D. M. (2017). Child Soldiers in the Western Imagination: From Patriots to Victims. New Brunswick: Rutgers University. 